\title{
RENAL FAILURE AND PERSISTENT HYPERTENSION IN A CHILD PRENATALLY EXPOSED TO LOSARTAN
}

\author{
Cinzia AURITI, Fiammetta PIERSIGILLI, Gabriella MARROCCO, \\ Mary HAYWOOD LOMBARDI, Andrea DOTTA
}

\author{
Department of Neonatology \\ Bambino Gesù Children's Hospital IRCCS \\ Rome, Italy \\ Corresponding author: \\ Cinzia Auriti \\ Department of Neonatology \\ Sub Intensive Care Unit \\ Bambino Gesù Children's Hospital IRCCS \\ Piazza S. Onofrio 4 - 00165 \\ Rome, Italy \\ cinzia.auriti@opbg.net \\ c.auriti@agtgroup.it \\ Tel.: + 390668592346 \\ Fax.: + 390668592832 \\ Received: March 10, 2013 \\ Accepted: May 1, 2013 \\ Copyright (C) 2013 by \\ University Clinical Center Tuzla. \\ E-mail for permission to publish: \\ paediatricstoday@ukctuzla.ba
}

\begin{abstract}
Objective - To underline the fetal kidney toxicity of losartan, an angiotensin receptor blocker (ARB), administered to a woman during pregnancy. Case report - We describe a male infant, prenatally exposed to losartan from week 32 of gestation, born at term by cesarean section due to maternal hypertension and oligohydramnios. The baby was admitted to the NICU of our hospital for anuria; he required peritoneal dialysis and survived the neonatal period. Presently, the child is 24 months old and is affected by severe chronic renal failure, failure to thrive and persistent hypertension. Conclusions - Although $\mathrm{ARBs}$ are recommended as first line antihypertensive agents, their administration should be avoided during pregnancy, especially from the second trimester onward. Most fetuses, affected by ARB toxicity, progress to death. The few that survive show serious outcomes. If a pregnant woman is under antihypertensive treatment with $A R B$, this has to be discontinued and replaced as soon as possible, and especially within the second trimester of pregnancy. Obstetricians should also be alerted of the potential risks of ARB administration beyond the first trimester of gestation.
\end{abstract}

Key words: Angiotensin receptor blockers - Neonatal renal failure Angiotensin converting enzyme inhibitors.

\section{Introduction}

The renin-angiotensin system (RAS) plays an important role in the regulation of the cardiovascular system and the homeostasis of body fluids. In addition to these physiological functions, RAS has other biological effects, such as cellular proliferation in the fetal kidney. Angiotensin II promotes cellular growth via angiotensin II type 1 receptor (AT1 receptor). This function is essential for the development of the kidney, especially in later fetal life. Drugs that have inhibitory activity on RAS may reduce nephron endowment, seriously impeding the normal development of the kidneys, and predispose to renal failure and hypertension in adulthood. Angiotensin converting enzyme inhibitors (ACEIs) or angiotensin receptors blockers (ARBs) control hypertension by interrupting the production or action of angiotensin II, the major endproduct of RAS. ARBs, as well as ACE-Is, are currently recommended as first line antihypertensive agents (1). Nevertheless, research 
carried out on animals and observations in humans recommend that their administration should be avoided in women during pregnancy. Many authors have described the association between maternal treatment with $A R B s$ in pregnancy, fetal renal failure and oligohydramnios, resulting in severe oligo-anuria, pulmonary hypoplasia, and congenital abnormalities of the skeleton and skull in the newborn (2-6). We report a case of adverse neonatal outcomes in a hypertensive pregnant woman exposed to losartan in the last trimester of gestation.

\section{Case report}

A $2320 \mathrm{~g}$ male infant, born at 38 weeks of gestational age by cesarean section due to maternal hypertension and oligohydramnios, was admitted to our NICU on the second day of life (DOL) for acute renal failure. Pregnancy was complicated by maternal hypertension treated initially with alpha-methyldopa 250 mg twice daily, progressively increased to 750 $\mathrm{mg}$ twice daily. Due to insufficient control of hypertension, losartan $50 \mathrm{mg}$ twice daily was added at week 32 of gestation. At 36 weeks a fetal ultrasound revealed oligohydramnios.

At birth, the newborn was in good health condition, with Apgar scores 8 and 9 at 1 and 5 minutes, respectively, and he was admitted to the nursery. At 48 hours of life the baby was still anuric and showed elevated levels of serum creatinine $(5.6 \mathrm{mg} / \mathrm{dl})$, blood urea nitrogen (BUN $25 \mathrm{mg} / \mathrm{dl}$ ) and potassium (7 mEq/l). Therefore, he was referred to our NICU. A renal ultrasound revealed bilateral renal length of $4.5 \mathrm{~cm}$ and parenchimal thickness of $9 \mathrm{~mm}$, increased cortical echogenicity and decreased corticomedullary differentiation. Despite an initial improvement in urine output, after Albumin 5\% and Furosemide administration, the renal function worsened (creatinine $6.7 \mathrm{mg} / \mathrm{dl}$, BUN $35 \mathrm{mg} / \mathrm{dl}$, potassium $7 \mathrm{mEq} / \mathrm{l}$ ), requiring peritoneal dialysis by DOL 7. Creatinine improved to $2.5 \mathrm{mg} /$ $\mathrm{dl}, \mathrm{BUN}$ to $13 \mathrm{mg} / \mathrm{dl}$ and potassium to 4.8 $\mathrm{mEq} / \mathrm{l}$; however, on DOL 11 , the baby developed Pseudomonas aeruginosa peritonitis that required antibiotic therapy. On DOL 20 , oral nifedipine was initiated for hypertension, (SBP 110-135, DBP 70-90 mmHg), and Doppler ultrasound showed increased renal artery resistance (Resistive Index 0.9-1) (Fig. 1).

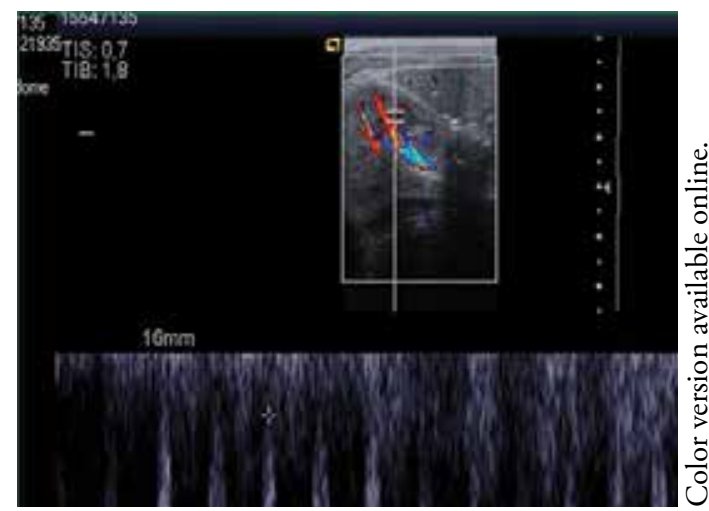

Fig. 1 Doppler ultrasound exam of the kidney at day of life 20 shows increased renal artery resistance and a decreased representation of intraparenchymal flow signals. On color Doppler the intraparenchymal resistive index ranges between 0.9 and 1 (normal values $0.6 \pm 0.01$ ) (12), especially in the sub capsular region of the kidney.

Dialysis was stopped on DOL 27. An Xray of the skull, upper and lower limbs excluded abnormalities; the echocardiography was normal. Upon discharge, on DOL 65, the baby was clinically stable under therapy, with feeding difficulties and tendency to vomit. Growth assessment showed weight $3.480 \mathrm{~g}$, height $50 \mathrm{~cm}$ and head circumference $35 \mathrm{~cm}$. All measurements were below the $3^{\text {th }}$ percentile. SBP was 80 and DBP 42 $\mathrm{mmHg}$ (mean $64 \mathrm{mmHg}$ ). Laboratory tests, showed moderate anemia $(\mathrm{Hb} 8.8 \mathrm{~g} / \mathrm{dl}$, RBC $3.430 .000 / \mathrm{mm}^{3}$, WBC $14.870 / \mathrm{mm}^{3}$, Plts $552.000 / \mathrm{mm}^{3}$ ), a creatinine level of 1.81 $\mathrm{mg} / \mathrm{dl}$ (range 0.2-0.8), BUN $14 \mathrm{mg} / \mathrm{dl}$ (range 5-18), sodium $141 \mathrm{mEq} / 1$ (range 136-145), 
potassium $5.97 \mathrm{mEq} / \mathrm{l}$ (range 3.5-5.1), calcium $10.6 \mathrm{mg} / \mathrm{dl}$ (range 8-10.5), phosphorus $7 \mathrm{mg} / \mathrm{dl}$ (range 3-6). The arterial blood gas analysis showed $\mathrm{pH} 7.37$ (range 7.32-7.48), pCO2 $37.5 \mathrm{mmHg}$ (range 32-48), $\mathrm{pO}_{2} 92.2$ $\mathrm{mmHg}, \mathrm{HCO}_{3} 21.6 \mathrm{mmol} / \mathrm{l}$ (range 19-27), Bases excess -3.2 mmol/l (range -2/+3). Urine had a specific gravity of 1005 . Urinalysis reflected increased protein excretion: 29 $\mathrm{mg} / \mathrm{dl}$ (range 0-15) with protein/creatinine ratio of 4.14 (range 0-0.15) and loss of bicarbonates. Therefore, the baby was discharged with ongoing therapy with amlodipine 0.3 mg twice/day, as well as calcitriol $0.25 \mathrm{mi}$ crograms three times/day, kayexalate $3 \mathrm{~g}$ by rectal route three times/day, and salts supplementation $\left(\mathrm{NaHCO}_{3} 3 \mathrm{mEq}\right.$ six times/day, Calcium carbonate $50 \mathrm{mg}$ six times/day), SC erythropoietin $1000 \mathrm{IU}$ three times/week.

At follow-up, performed at 12 months of age, the baby still showed persistent hypertension, despite therapy with amlodipine, the antihypertensive therapy was replaced with carvedilol $0.6 \mathrm{mg}$ twice/day and nifedipine 1 drop in case of arterial systolic pressure $>100 \mathrm{mmHg}$. Renal ultrasound performed at the same time showed right renal length of $4.3 \mathrm{~cm}$, with a parenchimal thickness of $8 \mathrm{~mm}$ and left renal length of $4.6 \mathrm{~cm}$ with a parenchimal thickness of $9.5 \mathrm{~mm}$, as well as increased cortical echogenicity and decreased corticomedullary differentiation.

Presently, the child is 24 months old, at the $3^{\text {rd }}$ centile for weight $(12.5 \mathrm{~kg})$ and height $(83 \mathrm{~cm})$ and, presents severe feeding difficulties, for which he is under rehabilitation treatment. His chronic renal failure is severe, with salt wasting and hypertension. Renal ultrasound shows bilateral reduction of renal size. Blood laboratory exams show serum creatinine $2,54 \mathrm{mg} / \mathrm{dl}$, BUN $31 \mathrm{mg} / \mathrm{dl}$ potassium $4.24 \mathrm{mEq} / \mathrm{l}$, sodium $140 \mathrm{mEq} / \mathrm{l}$, calcium $11 \mathrm{mg} / \mathrm{dl}$. Blood gas analysis shows $\mathrm{pH} 7.40$, $\mathrm{HCO}_{3} 28 \mathrm{mmol} / \mathrm{l}$, bases excess $-3.2 \mathrm{mmol} / \mathrm{l}$ ) The child requires oral salts supplementation,
$\mathrm{NaCL} 4 \mathrm{mEq}$ and $\mathrm{NaHCO}_{3} 6 \mathrm{mEq}$, three times/day, calcitriol 0.25 micrograms/day, allopurinol $25 \mathrm{mg}$ once/day, and antihypertensive therapy with ramipril (Triatec Aventis Pharma ${ }^{\oplus}$ ) $0.25 \mathrm{mg}$ two times/day. His BP under antihypertensive therapy is $83 / 52$.

\section{Discussion}

ARBs and ACE inhibitors alter the reninangiotensin aldosterone system, which plays a central role in renal cellular proliferation during fetal life (7). In fact, angiotensin receptors AT1 and AT2 are expressed from the $24^{\text {th }}$ day of gestation. AT1 receptors mediate the effects of angiotensin II on cell growth by inducing the secretion of the Tissue Growth Factor-beta 1 (8). AT2 receptors are expressed in the undifferentiated mesenchymal tissue and are responsible for the regulation of renal tubular development; their activation may influence proximal tubule sodium reabsorption (9). ARBs and ACE inhibitors administered to rats during fetal life can induce renal histological abnormalities, such as papillary atrophy, tubulo-interstitial fibrosis and tubular atrophy, resulting in suppression of fetal renal function and subsequently leading to oligo- or anhydramnios. Finally, fetal hypotension, resulting from maternal treatment with AT1 antagonist receptors and/or ACE inhibitors, may cause fetal renal hypoperfusion, leading to decreased glomerular filtration pressure, oligo-anuria and consequent oligohydramnios. Most fetuses affected by ARBs toxicity progress to death (2). The compression of the fetal chest wall, the restriction of the fetal breathing movements, and the decrease in the intrapulmonary pressure all together probably play a significant role, because oligohydramnios is responsible for severe pulmonary hypoplasia, especially if it is severe and prolonged over. Deformities of limbs, joint contractures and skull bone hypoplasia have also been described after pre- 
natal exposure to ARBs. The mechanism by which maternal treatment with ARBs cause hypoplasia of the fetal skull bones is not yet clear, but a combination of oligohydramnios and fetal hypotension with poor peripheral perfusion of superficial tissues may be involved (5). If the fetal exposure is of limited duration, renal injury may be reversible, and discontinuation of therapy results in restoration of an adequate amniotic fluid volume (10). Nevertheless, if such babies survive the neonatal period, they will later suffer from salt wasting, nephrogenic diabetes insipidus and failure to thrive (3) Not only experimental studies, but also case reports have shown that prenatally exposed children may develop hypertension later in life, even in the absence of neonatal problems. The blockade of the RAS with sartans in normal rats for the first 12 days after birth (the latter portion of nephrogenesis) leads to a reduced number of nephrons and hypertension in adulthood (11). Nevertheless, the information on longterm outcome in children is limited because very few infants with ACE inhibitors and ARB fetopathy survive.

In the case we reported, the fetus was exposed to $100 \mathrm{mg} /$ day losartan in the last six weeks of gestation, when nephrogenesis is in progress. As a consequence of the maternal treatment, the baby developed severely impaired renal function during fetal life and just after birth, but survived. To date, the child is affected by chronic kidney failure, severe growth retardation, chronic hypertension, thus requiring regular therapy.

\section{Conclusion}

$\mathrm{ARB}$ administration during pregnancy is associated with severe adverse effects on the fetal development, especially on the development of kidneys. If a pregnant woman is under antihypertensive treatment with ARBs, this has to be discontinued and replaced as soon as possible and, certainly within the second trimester of pregnancy. Obstetricians should also be aware of the potential risks of ARB administration throughout gestation, as this antihypertensive treatment must be replaced by drugs with less toxicity to the fetus, as soon as pregnancy is confirmed. Obstetricians have also be alerted that in cases of oligo or anhydramnios they should ask the patient for her drug history regarding recent ARB exposure as a potential cause. Finally pregnant women who have been treated with these agents during the second or third trimester of pregnancy should be referred to tertiary care centers for delivery.

Authors' contributions: Conception and design: CA, FP; Acquisition, analysis and interpretation of data: All authors; Drafting the manuscript: CA, FP; Revising it critically for important intellectual content: $\mathrm{CA}, \mathrm{AD}$.

Conflict of interest: The authors declare that they have no conflict of interest.

\section{References}

1. Hypertension: Clinical management of primary hypertension in adults. NICE guidelines February 2011. www.nice.org.uk/nicemedia/live

2. Spaggiari E, Heidet L, Grange G, Guimiot F, Dreux $S$, Delezoide AL. Renin-Angiotensin System Blockers Study Group, Muller F. Prognosis and outcome of pregnancies exposed to renin-angiotensin system blockers. Prenat Diagn. 2012;32(11):1071-6.

3. Miura K, Sekine T, Iida A, Takahashi K, Igarashi T. Salt-losing nephrogenic diabetes insipidus caused by fetal exposure to angiotensin receptor blocker. Pediatr Nephrol. 2009;24:1235-8.

4. Bullo M, Tschumi S, Bucher BS, Bianchetti MG, Simonetti GD. Pregnancy outcome following exposure to Angiotensing Converting Enzyme inhibitors or Angiotensin Receptor Antagonists. A systematic review. Hypertension. 2012;60:444-50.

5. Hünseler C, Paneitz A, Friedrich D, Lindner U, Oberthuer A, Körber F, et. Al. Angiotensin II receptor blocker induced fetopathy: 7 cases. Klin Padiatr. 2011;223(1):10-4.

6. Polifka JE. Is there an embryopathy associated with first-trimester exposure to angiotensin-converting 
enzyme inhibitors and angiotensin receptor antagonists? A critical review of the evidence.Birth Defects Res A Clin Mol Teratol. 2012;94(8):576-98.

7. Sekine T, Miura K, Takahashi K, Igarashi T. Children's toxicology from bench to bed--Drug-induced renal injury (1): The toxic effects of ARB/ ACEI on fetal kidney development. J Toxicol Sci. 2009;34 (Suppl 2):SP245-50.

8. Yang F, Chung AC, Huang XR, Lan HY. Angiotensin II induces connective tissue growth factor and collagen I expression via transforming growth factor-beta-dependent and -independent Smad pathways: the role of Smad3. Hypertension. 2009;54(4):877-84.
9. Wolf G. Angiotensin II and tubular development. Nephrol Dial Transplant. 2002;17:48-51.

10. Munk PS, von Brandis P, Larsen AI. Reversible fetal renal failure after maternal treatment with Candesartan: a case report. Reprod Toxicol. 2010;29:3812.

11. Woods LL, Rasch R. Perinatal ANG II programs adult blood pressure, glomerular number, and renal function in rats. Am J Physiol. 1998;275:159399.

12. Tublin ME, Bude RO, Platt JF. The Resistive Index in Renal Doppler Sonography: Where Do We Stand? AJR. 2003;180:885-92. 